John B. Taylor is a professor of economics at Stanford University. The article that follows is a reprint of The Homer Jones Lecture delivered at Southern Illinois University-Edwardsville on April 16, 1998. Kent Koch provided research assistance.

\section{Monetary Policy and The Long Boom}

\author{
J ohn B. Taylor
}

\begin{abstract}
regret that I never had the opportunity to work or study with Homer Jones. But I know people who worked and studied with him, and I have enjoyed talking with them and reading about their recollections of Homer Jones. What is most striking to me, of all that has been said and written about Homer Jones, is his incessant striving to learn more about economics and his use of rigorous economic research to improve the practical operation of economic policy. As a college student at Rutgers, Milton Friedman studied under Homer Jones. Friedman credits Jones as an essential influence on his own decision to study economics, and I want to begin this lecture with a quote from Friedman (1976, p. 436) describing certain features of Homer Jones character:
\end{abstract}

The hallmark of his contribution is throughout those same traits that exerted so great an influence on me in my teens: complete intellectual honesty; insistence on rigor of analysis; concern with facts; a drive for practical relevance; and, finally, a perpetual questioning and reexamination of conventional wisdom.

I am going to return to these character traits of Homer Jones later in this lecture for they are part of the story I want to tell.

\section{DE FINING “THE}

LONG BOOM"

I must begin by explaining what I mean by the term "The Long Boom" in the title of this lecture. This month (April 1998) the United States economy celebrates seven years of economic expansion. By definition an economic expansion is the period between recessions; that is, a period of continued growth without a recession. The last recession in the United States ended in April 1991, so as of this April we have had seven years of expansion and we are still going. This current expansion is a record breaker: to be exact it is the second longest peacetime expansion in American history.

But what is more unusual is that this current expansion was preceded by the first longest peacetime expansion in American history. That expansion began in November 1982 and continued through August 1990. It lasted seven years and eight months. Although the 1980s expansion was the first longest peacetime expansion in American history, the current expansion may very well continue long enough to become the first longest peacetime expansion. Either way, we are now experiencing back-to-back the first and second longest peacetime expansions in American history.

There is something even more extraordinary. The recession that occurred between these two record-breaking expansions wasat least for the economy as a whole- shortlived and relatively mild. Hence, during the last 15 years not only did we have the two longest peacetime expansions in American history, but the sole recession we had during these 15 years was remarkably short and mild. This 15-year period of unprecedented stability and virtually uninterrupted growth is what I refer to as the The Long Boom.

The Long Boom has another characteristic which I briefly mention now and discuss in more detail later, for it, too, is a part of the story I want to tell. The inflation rate has been very low and very stable during The Long Boom, much lower and much more stable than during the years immediately prior to The Long Boom.

Consider this long boom period in comparison with other periods in American 


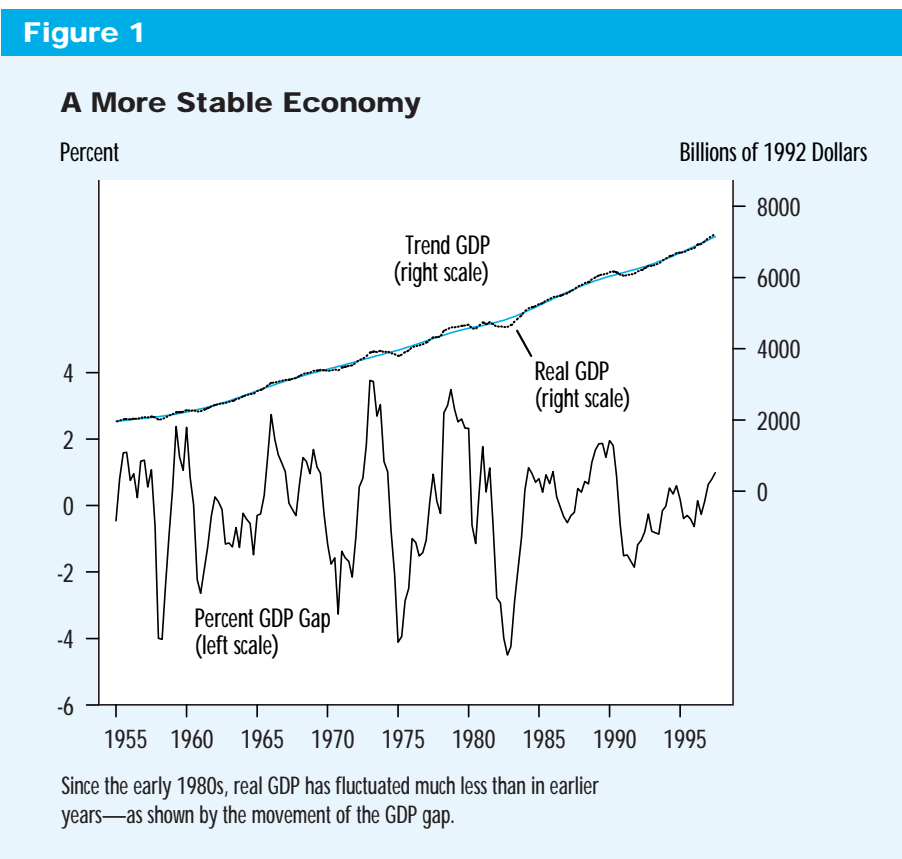

history. First, go back to the 15-year period before The Long Boom-the late 1960s and 1970s. In the same span of time we had four recessions, not one. The economy was much more unstable with many ups and downs. We also had the longest inflation in American history-a very unstable and high inflation-a remarkably different experience compared to the last 15 years. The economy was not performing well.

For another historical comparison, go back exactly 100 years, to the 1890s. Compare the 1890s with the 1990s. If the 1990 s were like the 1890s, we would have had a recession in 1990 or 1991 that was bigger, quite a bit bigger, than the one we actually had. And that would not have been the end of it. We would have had another recession in 1993, a big one, right when President Clinton was taking office. In 1996 we would have had yet another recession. We would have just been coming out of that recession now. So you can see how dramatically different the economy has been during The Long Boom. Times have changed.

Figure 1 helps visualize this. The upper part of Figure 1 shows real gross domestic product (GDP) in the United
States from 1955 to the present. You can see that the economy is growing. You can also see the ups and downs: the 1981-82 recession and recovery; and the 1990-91 recession and recovery. The trend line in Figure 1 shows where the economy is going in the longer term. The lower part of Figure 1 nicely illustrates the large change in economic stability. It's like a microscope that focuses on the fluctuations in real GDP around trend GDP. It shows the GDP gap, which is defined as the percentage difference of real GDP from trend GDP. On the right is where we have been recently. On the left is where we were before. You can see clearly in Figure 1 that the ups and downs- recession, expansion, recession, expansion-are much milder and much less volatile in the latter period than in the earlier period. During The Long Boom, there is obviously greater stability. This greater stability is one reason why the stock market has boomed during the same period, 1982 to the present.

\section{EXPLAINING THE LONG $\mathrm{BOOM}$}

What are the underlying reasons for this remarkable and unprecedented period of economic performance in America? $M$ any explanations have been offered. Some have to do with inevitable changes in the structure of the economy that have had the fortunate by-product of a more stable economy. Other explanations are related to economic policy-deliberate decisions of economic policymakers to change policy. So which is it? Good fortune or good economic policy? Let us consider each in turn.

\section{Good Fortune?}

Many have noted that the U.S. economy is much more service-oriented now than it was in the past. Services- educational services, legal services, financial services-are generally not as cyclical as manufactured goods, such as automobiles or airplanes. Recessions hit manufacturing sectors quite hard. But in the service industries, busi- 
ness-cycle fluctuations have been typically small. So maybe The Long Boom, with its greater stability, is due to the economy becoming more service-oriented. The problem with this explanation is that the move to a service-oriented economy has been a very gradual change occurring over many decades. It could not explain the sudden shift toward greater economic stability in the early 1980s shown in Figure 1. Hence, a more service-oriented economy is unlikely to be an explanation.

Others have noted better control of inventories. It is true that inventory sales ratios are lower now because inventories are being managed better. The just in time approach to inventory management is now much more common. During most ups and downs in the economy, inventories fluctuate widely. As the economy starts to dip, firms want to cut their inventories; they reduce their orders, and production falls even more rapidly. Thus, better control of inventories may be an explanation for this greater stability that defines The Long Boom. But this explanation also has problems. If you take out the fluctuations of inventories and look at what is left over-final sales-you see virtually the same amount of improvement in economic stability. That is, if I replaced real GDP with final sales of goods and services in the economy in Figure 1, it would look essentially the same.

A very common explanation of The Long Boom is that the U.S. economy has been lucky with respect to the shocks hitting the economy. Recall that in the 1970 s we had several large oil shocks. In the 1980s and 1990s we seem to have had fewer oil shocks. But for two reasons I must reject this explanation, too. First, the poor economic performance, along with the higher inflation, that we experienced in the 1970s really got started before the oil shocks began. Second, the U.S. economy had serious shocks in the 1980s and 1990s, including the savings and loan crisis, the oil shock when Iraq invaded Kuwait, and the East Asian crisis.

Now let us move on to economic policy as a possible explanation of The
Long Boom. There are, of course, two aspects of economic policy one should focus on: fiscal policy and monetary policy. Let us consider fiscal policy first.

\section{Fiscal Policy}

Has fiscal policy seen a major change that could have led to The Long Boom? What about government budget deficits? Budget deficits were huge throughout the 1980 s and much of the 1990s. Budget deficits were smaller in the late 1960s and 1970s. Therefore a smaller budget deficit does not seem plausible as an explanation for The Long Boom.

What about the ability of government fiscal policy to respond to recessions by lowering taxes or increasing spending? $\mathrm{H}$ as that response gotten larger, quicker, or more efficient? No. In fact, if anything, the ability of the federal government to make discretionary fiscal policy changes to mitigate or offset recessions has diminished. President Bush proposed a small economic stimulus package to be put in place at the end of the 1990-91 recession, but Congress rejected it. In 1993 President Clinton al so proposed an economic stimulus package and again the Congress rejected it. Hence, I have to rule out fiscal policy- either smaller budget deficits or better countercyclical policy-as a possible explanation of The Long Boom.

\section{Monetary Policy}

Now consider monetary policy. As is probably already obvious, I will argue that monetary policy is the key factor behind The Long Boom. To do so, I must first discuss briefly the monetary transmission process in the United States. Monetary policy is, of course, the responsibility of the policymakers who serve on the Federal Open Market Committee (FOMC). The ultimate tool of monetary policymakers is the money supply. An increase in money supply growth will lead eventually to an increase in inflation. However, the FOMC actually carries out its money supply decisions by focusing on the short-term 


\section{Figure 2}

\section{A Change in Monetary Policy}

Interest Rate

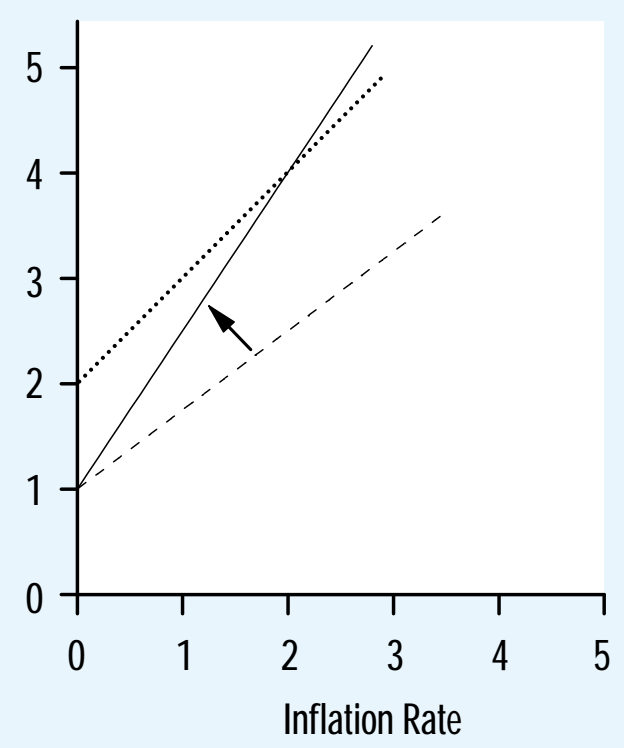

The response of the federal funds rate to changes in inflation is more aggressive (solid line) in The Long Boom than in the prior 15 years (dashed line). The dotted line has a slope of 1 and represents a constant real interest rate.

interest rate- the federal funds rate- that commercial banks charge when they loan funds to each other. The federal funds rate is the instrument of policy that the FOMC members vote on. The federal funds rate, of course, has a big impact on all other interest rates, especially other short-term interest rates, but also on longer-term interest rates. Interest rates have a big effect on the economy. Higher interest rates tend to slow down the economy; lower interest rates tend to stimulate the economy. To be sure, these changes in interest rates are closely related to the money supply, and if the FOMC tried to keep interest rates too low for too long, the money supply would have to increase and this would cause inflation to rise.

When the members of the FOM C make decisions about the interest ratewhether back in the 1970s or today-they look at a number of factors, including the inflation rate and real GDP. Is it possible to see a change in this decision-making process that could explain The Long Boom? Has anything important changed about monetary policy? To explore these questions, consider a numerical example that illustrates how the FOMC might respond to a change in the economy, such as an increase in the inflation rate. First, imagine that the FOMC gets reports that the inflation rate is 1 percentage point higher. Let us suppose that in this circumstance the FOMC decides to raise the federal funds rate by .75 percentage points. The inflation rate is up by 1 percentage point, and the interest rate is up by three-quarters of a percentage point. The FOMC has raised the interest rate in response to inflation. But what happened to the difference between the federal funds rate and the inflation rate, a measure of the real interest rate? According to this measure, the real interest rate has gone down by a quarter of a percentage point. In other words, the federal funds rate did not go up by enough to raise the real interest rate. It is the real interest rate that affects spending. So by allowing the real interest rate to fall, the FOMC would be doing exactly the opposite of what it should do when the inflation rate rises. The FOMC members would be voting to stimulate the economy just when they should be trying to cool off an inflationary surge. So this policy, with a response of .75 percentage points, is not a good policy. It adds fuel to the inflation fire.

Now consider an alternative monetary policy response. Again, start with the same scenario: The inflation rate rises by 1 percentage point. But now suppose the FOMC, instead of raising the federal funds rate by .75 percentage points, raises it by 1.5 percentage points. In other words, as the inflation rate goes up by 1 percentage point, the interest rate goes up by 1.5 percentage points. The real interest rate now goes up by half a percentage point, and that is the right thing for the FOMC to do. The FOMC has removed fuel from the inflation fire because the higher real interest rate is going to reduce demand for automobiles, houses, and other goods. Even though in 
both cases the $\mathrm{FOMC}$ raised the interest rate when inflation rose, in one case the policy was right, and in the other case the policy was wrong.

In fact, these two cases are not hypothetical examples. They turn out to be actual descriptions of monetary policy before and after the start of The Long Boom, respectively. The first case characterizes monetary policy during the late 1960 s and 1970 s period, while the second case characterizes monetary policy during The Long Boom of the 1980s and 1990s.

By responding in this more aggressive way during The Long Boom, the Federal Reserve (the Fed) has been able to keep the inflation rate lower and much more stable than in the earlier periods. In my view, that change in policy has been the key to keeping the real economy stable. Every recession in the post-World War II economic history of the United States has been preceded by a run-up of inflation. So by keeping the inflation rate low and stable through this policy (taking the fuel off the fire when inflation heats up) the Fed has succeeded in stabilizing the economy, and making recessions less frequent, smaller, and shorter. That has made all the difference, which Figure 2 illustrates. The graph has the interest rate- in particular, the federal funds rate, the variable that the FOMC is making decisions about- on the vertical axis. On the horizontal axis is the inflation rate. The dashed line is the bad policy, where the coefficient is .75. For this policy, when the inflation rate rises by 1 percentage point, the FOM C raises the interest rate by only .75 percentage points. For the solid line, when the inflation rate rises by 1 percentage point, the FOMC raises the interest rate by 1.5 percentage points. For reference, I also show a dotted line in Figure 2 for which the response is exactly one. The real interest rate is constant along that line. By being more responsive than that dotted line, the Fed lets the real interest rate rise when inflation rises. By being less responsive (following the dashed line), the Fed lets the real interest rate fall when inflation rises. These two lines characterize the decisions of the Fed. Although this may sound like an overly simple description of how the Fed makes its decisions, it is actually very accurate. Empirical estimates of the Fed's reaction function (regressions of the interest rate on inflation and other variables) show that the dashed line corresponds to the late 1960s and 1970s period (the great inflation and all those business cycles) and the solid line refers to the more peaceful economic times associated with The Long Boom.

What are the implications of this assessment of policy for the future? Put as simply as possible, the Fed should continue to respond to inflation according to a 1.5 response coefficient. If it continues doing that, it will be able to keep the economy stable, making future long booms more common, not avoiding recessions completely, of course, but making recessions smaller and less frequent. Focusing on keeping the inflation rate low and stable and responding aggressively with interest rates is the most important thing the Fed can do to keep the economy stable.

\section{WHY THE CHANGE IN MONETARY POLICY?}

Now, what has caused this shift in monetary policy? Did economic research play a role? To answer these questions we must look at some of the history of the Federal Reserve. Go back to the 1950s. The 1951 Accord between the Federal Reserve and the Treasury released the Fed from the job of assisting the Treasury borrowing by keeping interest rates low, as it had done during World War II. But after the Accord, the Fed actually had to decide what to do with the interest rate. One widely discussed suggestion was to lean against the wind, raising the interest rate when the economy grew more rapidly or inflation started to pick up. Leaning against the wind seemed to have the directions of interest rate adjustments right, but it had nothing to say about the size of the adjustments. What is the wind? How do you measure it? What do you lean with and by how much? There were many important, but unanswered, questions. 
Meigs (1976, p. 440) described the situation in the 1950s as follows,"...The Manager [of the open market account] generally tried to keep free or net borrowed reserves... at a level, he thought would satisfy FOMC members' desires for a little more, or a little less, or about the same 'degree of restraint."' But the degree of restraint was not quantitatively defined and the impact of changes in the degree of restraint was uncertain. As M eigs (1976) put it, "We were as uncertain about how monetary policy worked as were our colleagues at the other Reserve Banks and the Board." A similar accounting comes from Board member Sherman Maisel (1973, p. 77), who admitted "that after being on the Board for eight months and attending twelve open market meetings, I began to realize how far I was from understanding the theory the Fed used to make monetary policy... N owhere did I find an account of how monetary policy was made or how it operated."

This was the situation when Homer Jones arrived at the research department of the Federal Reserve Bank of St. Louis in 1958. He and others were uncomfortable with this vagueness and uncertainty about the operations of monetary policy, and he tried to make the FOMC decisions more specific. The vagueness was why, according to M eigs (1976), Homer Jones "undertook the extraordinary program of monetary research to which all of us are indebted today."

The research program undertaken by Homer Jones helped change this situation in several ways. First, the research improved the money supply statistics. This allowed policymakers to see how money supply growth targeting would work and to measure the movement in interest rates that would accompany money growth targets. The St. Louis Fed Model of the U.S. economy provided an analytical structure through which different monetary policy procedures could be explored. The research was also essential in helping policymakers distinguish between real interest rates and nominal interest rates. The neglect of this distinction is at the heart of the poor monetary policy performance in the late 1960s and 1970 s when the interest rate reaction was too small. One can easily imagine how useful
Homer Jones' character traits (quoted from Milton Friedman at the start of this lecture) were for stimulating and motivating others to carry out this important research agenda.

In my view, the research directed by Homer Jones was an essential part of a gradual process through which the Fed learned more about the conduct of monetary policy. Of course, others participated in this processthe staff at the Federal Reserve Board and other District banks as well as academic economists. In my view, the result of this gradual learning process was a recognition by the 1980s that changes in interest rates had to be larger and quicker if they were to keep inflation and the overall economy stable. Focusing on the monetary aggregatesespecially during the disinflation period of the late 1970s and early 1980s when interest rates had to rise by a very large amountand emphasizing the distinction between the real and nominal interest rate were part of the means towards this end. Of course, there were other factors that led to the change in monetary policy. The Fed learned from the great inflation experience of the 1970s and discovered through increasing evidence that there was no long-run Phillips curve tradeoff.

\section{A PROBLEM WITH THE LONG BOOM}

So far in this lecture I have emphasized the many good features of The Long Boom and the role of economic policy in helping to bring them about. Now let me move on to some not-so-good features and the role that economic policy might have in alleviating them. These policies are what we should focus on in the future.

The main problem with The Long Boom is that productivity growth is much lower than during past periods of U.S. history. By definition, productivity is the amount that workers produce on average during a given time at work. Labor productivity growth means that for the same number of hours of work, a worker can produce more. Productivity growth is the means through which people improve their living standards, because more production per worker means 
that workers can earn more. Productivity growth is why the standard of living is now so much higher than it was in the days before the industrial revolution.

Productivity growth in the 1950s and 1960 s was about 2 percent per year. During the period of The Long Boom, productivity has been about 1 percent per year. Steady 2 percent per year productivity growth means that the average worker in America can produce 2 percent more next year compared to this year for the same amount of time on the job, and 2 percent more the next year and so on. The 2 percent accumulates and compounds. Unfortunately, the data indicate that productivity growth is only half as much as it was in the 1950s and 1960s.

$\mathrm{N}$ ow, to be sure, there are some signs that productivity growth has increased recently. In fact, a recent buzzword in the financial press is the "New Economy." The New Economy is characterized by higher productivity growth. Others argue that there is a problem in measuring productivity, especially in a computer age, and that productivity is actually higher than we think. Still others have argued that an even bigger productivity spurt is about to happen: We have all this great technology - computers, biotech, and telecommunications- ready to be used in the workplace to make people more productive. But, in my view, it is too soon to conclude that we are now in a period of persistently higher productivity growth. If productivity has not, or does not, pick up, then improvements in living standards are going to be much less than in most of U.S. history.

If we could get productivity growth up by 1 percent per year, from 1 percent to 2 percent per year, it would make a huge difference for the future. AsI noted, that would take us to where productivity growth was in the 1950s and 1960s. Such a growth rate would remove many problems facing us in the future: Social security would no longer be the problem it is today, the income distribution would improve, and poverty rates would decline. That is what happened during the 1950s and early 1960s when productivity growth was very strong. The income distribution narrowed, because the productivity gains spread across the whole population.

\section{A GOAL}

I propose that we adopt a goal. The goal is much easier to write down than to carry out. I write in bold-faced characters: $+1 \%$. The goal is to raise productivity growth by 1 percentage point per year, so that productivity growth averages 2 percent per year for the 21st century. In other words, we would see 2 percent per year productivity growth rather than 1 percent per year productivity growth for the next 100 years.

Now, I will be the first to admit that this is a goal that is very difficult to achieve. But I think goals are useful for bringing attention to a problem, for focusing policymakers efforts, and simply for getting things done. Even if we got hal fway to that $+\mathbf{1} \%$ goal, it would make a tremendous difference. The U.S. economy reached that 2 percent goal in the past, so it may indeed be achievable.

What can we do to help achieve the $+1 \%$ goal? By way of offering some examples, I would like to mention four economic policy measures that-taken together-would achieve the goal. But the important point is that setting such a goal would improve the debate about policy al ternatives that have the best chance of achieving the goal.

Let us consider budget policy first. The debate about the federal budget has changed remarkably in the last two years, from debate about how to end the deficit to a debate about how to use the surplus. Simply running a budget surplus would help achieve the productivity growth goal. Why? Because by running a budget surplus, the federal government can add saving to the economy rather than subtract saving from the economy. More saving means more investment, raising capital, and increasing productivity. However, it is nearly impossible for politicians to run a budget surplus for any length of time. Every time we have seen projections of surpluses in the past, we also have seen proposals for spending the surpluses. And, of course, spending the surplus means we do not have a surplus.

Thus, a better approach is to establish a fiscal policy that will increase economic 
growth that does not require running a surplus. One idea is a recent proposal to partly privatize social security. It would use the projected surplus to allow people to put funds equal to a fraction of their payroll tax into a private savings account. Those funds would then be part of national saving and would increase investment, and thereby increase productivity growth. Other people might have other ideas; with the $+1 \%$ goal in mind, those alternatives can be discussed and debated.

Second, consider tax reform. Several proposals for tax reform would increase productivity growth. A flat tax, by exempting investment from taxation, would stimulate investment. Replacing the income tax with a retail sales tax would increase the tax on consumption relative to saving, encouraging people to do more saving. Permitting people to save in more tax exempt accountsextensions of the educational savings accounts and IRAs- would increase saving. Again there are alternatives, but with $+\mathbf{1} \%$ goal, we would have to adopt one of them. Next, consider education reform. I think this is the most important thing we can do for productivity growth, though the payoff will not start right away. Education reform would address the problem of workers not having enough skills or enough training to make use of new technology in the workplace. Education reform is controversial. I am in favor of greater choice of schools through vouchers, but again the point here is to discuss, debate, and adopt some reform that will help achieve the $+1 \%$ goal.

Finally, consider regulatory policy. The United States has had deregulation of entry and price in a number of industries including trucking, airlines, and telecommunications, and that has been good for the economy. But there is another kind of regulation called social regulation-which includes environmental regulation, work and safety regulation - that has not been reduced. These types of regulations affect everyone, not only business firms. At my university, for example, one can see many examples where regulations, not just from the federal government but also from the state and local governments, interfere with production - in our case the production of research and teaching. To reduce this interference and stimulate productivity growth, we should have a regulatory policy that applies an effective cost/benefit criterion. If there is going to be a regulation imposed on a university, on a private business, on any other organization, it should pass the criterion that any other good policy would pass - that the benefits outweigh the costs.

\section{CONCLUSION}

In summary, during this lecture I have pointed out both the good and the bad of this period that I have called The Long Boom. As I see it, monetary policy deserves much of the credit for what is good-the unprecedented degree of economic stability. Of course, there will be recessions in the future, but if the Fed can maintain the kind of monetary policy rule we have had during The Long Boom and if the same type of monetary policy can be used by other central banks in the world, then more long booms will occur in the future.

Even with such stability, however, if the United States is not successful in developing and implementing economic policies to raise productivity growth, then the 21st century will not be one of much progress and the current problems of social security and income distribution will get worse. If the United States is in a period of a N ew Economy, as some argue, then it only just arrived and we should adopt policies to maintain it. If the United States is not yet in a period of a $\mathrm{N}$ ew Economy, which is more likely in my view, then we should adopt policies to establish it. That is the purpose behind the $+1 \%$ goal for productivity growth that I suggested.

I am sure rigorous economic research of the kind Homer Jones advocated, directed, promoted, and carried out will be essential to developing and adopting policies to raise productivity growth and achieve such a goal. We need a new Homer Jones to help us find policies for economic growth just as we were 
lucky to have had the original Homer Jones to help us find policies for economic stability.

\section{REFERENCES}

Friedman, Milton. "Homer Jones, A Personal Reminiscence," Journal of Monetary Economics (November 1976), pp. 433-36.

Maisel, Sherman J. Managing the Dollar, W.W. Norton \& Company (1973).

Meigs, A. James. "Campaigning for Monetary Reform: The Federal Reserve Bank of St. Louis in 1959 and 1960," Journal of Monetary Economics (November 1976), pp. 439-53. 
NOVEMBER/ DECEMBER 1998

FEDERAL RESERVE BANK OF ST. LOUIS 